\title{
Growth and nutrient uptake among three wetland plant species occurring in Lake Victoria basin in Kenya.
}

\author{
D. M. Musyimi, G. W. Netondo , B. Owuor and B. M. Gichimu \\ Department of Botany and Horticulture, Faculty of Science, Maseno University, P.O BOX 333, Maseno, Kenya. \\ Email: davidmusyimi2002@yahoo.com
}

\begin{abstract}
Nutrient enrichment is one of the most serious threats to wetland ecosystems. Information is lacking, particularly concerning the response of wetland plants species in Kenya in regard to nutrient enrichment of wetlands. Understanding the mechanisms and adaptations that allow only certain species to thrive in the potentially stressful wetland environment requires the study of the biology of these plants. This study was carried out to investigate the growth and nutrient uptake among some selected wetland plant species in Lake Victoria basin, Kenya. Seedlings of Cyperas esculentus L., Aframomum angustifolium (Sonn.) and Phragmites australis (Cav.) Trin. Ex Steudel) were grown outdoors in pots. The pots were arranged in a completely randomised design under out-door conditions in the Botanic garden at Maseno University. Plants were provided with four nutrient dosage levels of $0 \mathrm{mg}$ [no fertiliser added], $50 \mathrm{mg}, 100 \mathrm{mg}, 150 \mathrm{mg}$ fertilizer [N: P: K, 10:26:10] per pot and replicated five times. The plants were irrigated daily with tap water for eight weeks. Data on growth which included shoot height, stem diameter, leaf number per plant, leaf area, leaf width, leaf length, shoot and root weights were determined. Leaf $\mathrm{N}$ and $\mathrm{P}$ was also determined. The data were analysed by analysis of variance (ANOVA) in SAS statistical package. Nutrient availability treatments significantly $(P \leq 0.05)$ influenced the growth and biochemical parameters investigated. Cyperas esculentus and $A$. angustifolium had higher rate of biomass accumulation as evidenced by increase in shoot and root weights compared to $P$. australis. Root-shoot ratios reduced with increasing nutrient concentration in $C$. esculentus and $A$. angustifolium, while that of $P$. australis increased up to $100 \mathrm{mg}$ treatment, then slightly reduced at $150 \mathrm{mg}$ treatment. Phragmites australis had significantly higher foliar $\mathrm{P}$ and $\mathrm{N}$ content than the other two species with increasing nutrient availability. There were significant interactions between nutrient treatments and species in most of the parameters measured. We recommend Phragmites australis as a better agroforestry plant species for reclaiming wetland areas.
\end{abstract}

Keywords: Aframomum angustifolium, Cyperas esculentus, growth, nutrient uptake, Phragmites australis.

\section{INTRODUCTION}

Wetlands are an integral part of the hydrological cycle, playing a key role in the provision and maintenance of water quality and quantity as the basis of all life on earth. Land use practices exert a major influence on plant productivity, soil and plant nutrient content, and within-stand nutrient cycling in wetlands in agricultural landscapes (Gathumbi et al., 2005). Among the variety of substances entering the soil, inland waters and the ocean as waste products, nutrients especially create long term problems. Besides climatic and endogenous factors of the plants themselves, the supply with mineral nutrients plays a major role for distribution of plants. Nitrates, ammonium, or simple organic compounds such as amino acid and urea are the major sources of inorganic nitrogen taken up by the roots of higher plants and thus are decisive factors for plant growth (Janiesch, 1991). Hydrological patterns can determine the vegetation in natural and man-made wetlands, since the vegetation is dependant on ecophysiological adaptations of species (Jackson and Colmer, 2005). Increased use of inorganic fertilizers associated with agricultural activities is known to increase both particulate and dissolved nutrients particularly $P$, in sediments and surface water and overland flow (Gathumbi et al., 2005). In agricultural areas where wetlands are an important feature of the landscape, fertilizer applied to field crops or pastures may enter adjacent wetlands via inadvertent overspreading of fertilizer or as particulate runoff or ground water (Qualls and Richardson, 1995). The nutrient assimilative and storage capacity of seasonal wetlands embedded 
within agricultural landscapes determines their role as nutrient sinks, but also as potential nutrient sources within the landscapes (Gathumbi et al., 2005).

Species composition influences nutrient retention of ecosystems because individual species differ in their tissue nutrient quality (Tilman et al., 1997). In wetlands, human activities can have profound effects on plant community composition and ultimately ecosystem function. Developing an understanding of how species respond to those activities is essential to predicting the impacts of human activities on both species composition and ecosystem function.

Human disturbances to wetlands are frequently the result of agricultural practices and urban development (Galatowitsch et al., 2000), and their impacts can be divided into individual stressors that may have physical, chemical, and/or biological effects on wetlands. Many changes are typical of nutrient enrichment, including increased biomass production, dominance of faster growing plant species, accelerated $\mathrm{N}$ cycling and reduced $\mathrm{N}$ retention (Aerts and Chapin, 2000). The content of phosphorus in wetlands has greatly increased as a result of discharge of phosphates from rivers. In an experimental study application of sewage sludge to the Great Sippe Wisset salt marsh in Northern America, plant biomass increased significantly in the upper and lower parts of the salt marsh (Rozema and Leendertse, 1991). The tall form of Spartina alterniflora in the lower parts of the salt marsh increased strongly with nutrient enrichment (Rozema and Leendertse, 1991). The allocation of biomass to different plant organs depends on species, ontogeny and on the environment experienced by the plant (Poorter and Nagel, 2000). Turnover rates for both above and below-ground tissues vary depending on the plant species and tissue type (Neubauer et al., 2000). In wetland ecosystems dominated by perennial plants, there can be significant translocation of nutrients and energy from below ground to above ground components as aboveground tissues senesce (Neubauer et al., 2000). At low nutrient and water availability, roots use relatively more of the limiting amounts of photosynthates, leaving less for the shoots (leaves) (Poorter and Nagel, 2000). Studies have revealed the presence of both $\mathrm{C}_{3}$ and $\mathrm{C}_{4}$ species as dominants in different parts of small wetlands in Kenya (Jones, 1988). Some of the wetland species commonly encountered in Kenya, include papyrus (Cyperus papyrus, Cyperus latifolius ) and Typha domingensis. Other wetland plant species include Cyperus rotundus,
Cyperus esculentus, Typha angustifolia, Phragmites australis, and Aframomum angustifolium.

Knowledge of the increasing nutrient levels in wetlands on growth, biomass accumulation and nutrient uptake of plants is still lacking in Kenya to reasonably predict the impacts of excessive nutrients on the future wetland plant species. The main objective of this study was to determine the effect of different levels of nutrient availability on growth and nutrient uptake in $C$. esculentus, $A$. angustifolium and $P$. australis which are some of dominant wetland plant species in L. Victoria region, Kenya. We hypothesised that there are significant variations in growth, and nutrient uptake among the wetland plant species under changing ecological conditions induced by human activities such as excessive NPK fertilization.

\section{MATERIALS AND METHODS}

Study sites and species: Field surveys were conducted at Maseno university botanic garden swamp (latitude $0^{0} 1^{\prime} \mathrm{N}-0^{0} 12^{\prime} \mathrm{S}$ and longitude $34^{0} 25^{\prime} \mathrm{E}$ - 47'E, altitude is $1500 \mathrm{~m}$ above sea level) and Nyamasaria swamp (Latitude $0^{0} 50^{\prime} \mathrm{S}-0^{\circ} 45^{\prime} \mathrm{N}$ and longitude $33^{0} 20^{\prime} \mathrm{E}-35^{\circ} 20 \mathrm{E}$ ), to assess species diversity of the changing wetlands. Based on the initial surveys the dominant plant species from each of these two sites: Cyperus esculentus L. Phragmites australis (Cav.) Trin. Ex Steud and Aframomum angustifolia (Sonn.) were selected for detailed physiological and biochemical studies. The ecophysiology and genetic variation of the plants was evaluated in a pot experiment, the plants were grown under well drained conditions.

Growth conditions and Experimental design: Seeds of Aframomum angustifolia (Sonn.) were collected from Maseno university Botanic garden and germinated within the glasshouse in small plastic containers $(10 \times 15 \times 4 \mathrm{~cm})$, containing river sand. After germination the seedlings were transplanted at the age of three weeks into polythene bags containing a 1:3 mixture of soil and river sand and were irrigated with water in a nursery for seven months.

Small rhizome sections (approximately $5 \mathrm{~g}$ each) of Cyperus esculentus L. and Phragmites australis were collected from Nyamasaria swamp and Maseno university botanic garden swamp respectively. The rhizomes sections were transplanted in 3.5 litre pots, one plant per pot containing a 1:3 mixture of soil and river sand. The Pots were irrigated with tap water to initiate shoots prior to the treatments. Potted plants were acclimatized for three weeks before initiating 
experimental treatments. The pots were arranged in a completely randomised design under out-door conditions in the Botanic garden at Maseno University. Plants were provided with four nutrient dosage levels of $0 \mathrm{mg}$ [no fertiliser added], $50 \mathrm{mg}$, $100 \mathrm{mg}, 150 \mathrm{mg}$ fertilizer [N: P: K, 10:26:10] per pot with modification from Pons and Westbeek (2004), and replicated five times.. The plants were irrigated daily with tap water for eight weeks. Photosynthetically active radiation (PAR) during the study period ranged between $500-2020 \mu \mathrm{mol}$ photons $\mathrm{m}^{-2} \mathrm{~s}^{-1}$, day temperatures ranged between $22-33^{0} \mathrm{C}$ and relative humidity was between $30-50 \%$.

\section{Measurement of growth parameters}

Plant height : Plant height was measured from ground to the top most internode of the shoot by use of a metre rule at the end of the experiment.

Stem diameter Stem diameter was measured at the base of the stem $(10 \mathrm{~cm}$ from the soil level) using a vernier calliper at the end of the experiment.

Leaf number: Number of leaves on each shoot was counted at the end of the nutrient treatment experiment.

Leaf area: Areas of leaves were determined according to Jose et al. (2000) using the following equation: $A_{L}=0.73\left(L_{L} \times W_{L}\right)$ where $A_{L}$ is the leaf area, $L_{L}$ is the length of the leaf blade and $W_{L}$ is the maximum width measured for each leaf. The product of both was an estimate of leaf area. Leaf length and maximum width were measured by use of a micrometer and a transparent ruler.

Leaf length and leaf width: Length of the leaf blades and maximal width of the largest leaf from each plant were measured at the end of the study using a micrometer and a transparent ruler.

Root and shoot weights: Upon completion of the experiment, plants were harvested. Roots were gently washed and carefully separated from soil, sand and other debris using the sieve method, and blotted dry on paper towels. Harvested plants were grouped in envelopes by pot. Shoot and root fresh weights of the three plant species were determined using a weighing balance immediately after harvesting. Plant components were labelled and oven dried for at least 48 hours at $80{ }^{\circ} \mathrm{C}$ to constant weight to determine dry weight so that biomass could be calculated per stem and per species. To derive average individual biomass, total pot biomass was divided by number of individuals/pot for each pot. Average biomass figures were an attempt to account for differences in number of individuals/pot. Dry weights of each organ part were considered a measure of photosynthate partitioning and allocation.

Root-shoot ratio: Root-shoot ratio was determined using dry weight of roots and shoots from each pot.

Foliar mineral analysis: Foliar mineral analysis of green fully expanded leaves from the three species, for total $\mathrm{N}$ and $\mathrm{P}$, was carried out. Four oven dried leaf samples were extracted by acid digestion method following the Kjedahl procedure, and determined colorimetrically in an analyser.

Data analysis: Analysis of variance (ANOVA) was carried out on the data for the variables measured during the study period to test for differences between the treatments and plant species by use of SAS statistical computer package. Treatment means were separated using the least significant difference $($ LSD) test $(P=0.05)$.

\section{RESULTS}

\section{Plant growth parameters}

Shoot height: Shoot height growth slightly increased in $A$. angustifolium and $P$. australis with increasing nutrient availability, but reduced in $C$. esculentus (Figure 1).There was a significant difference in shoot height growth among the three plant species ( $P \leq$ 0.05 ), primarily reflecting somewhat a slightly higher growth rate in $P$. australis than in the other two species. There was no significant interaction between species and nutrients availability (Table 1).

Stem diameter: There were significant differences $(P \leq 0.05)$ between nutrient availability treatments and among species in this parameter. Stem diameter of $A$. angustifolium steadily increased with increase in nutrient availability from 0 to $100 \mathrm{mg}$ treatments, and then stabilised between 100 and $150 \mathrm{mg}$ treatment. While that of $C$. esculentus and $A$. angustifolium decreased slightly with increase in nutrient availability (Figure 2). The mean for the four nutrient availability treatments was slightly but significantly higher for $C$. esculentus (a mean of $2.6 \mathrm{~cm}$ ) compared to $A$. angustifolium $(1.92 \mathrm{~cm})$ and P.australis (1.04 $\mathrm{cm})$.Furthermore, there was a highly significant interaction between nutrient treatment and species (Table 1). 
Agric. Biol. J. N. Am., 2010, 1(3): 250-264

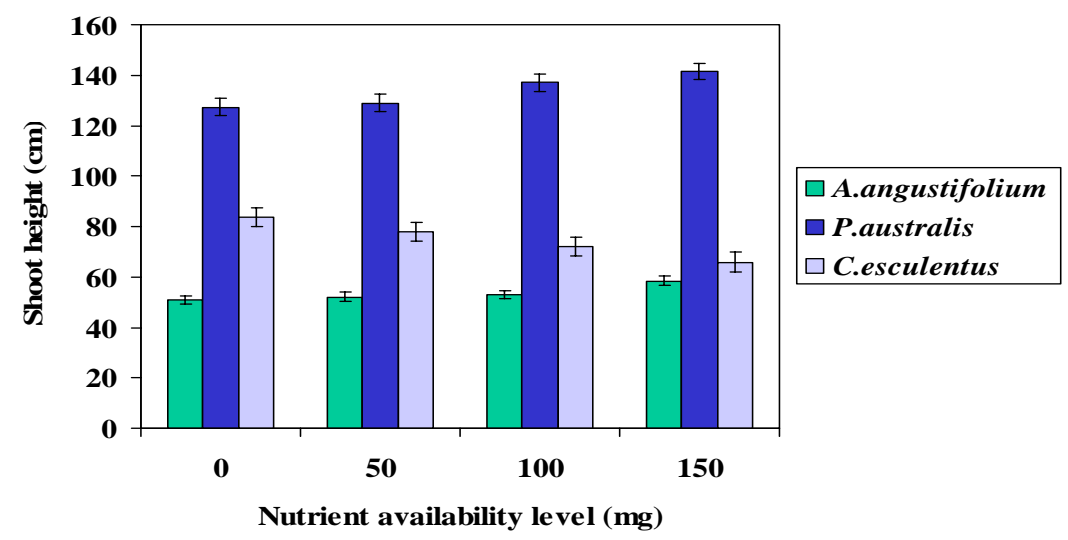

Figure 1. Shoot height growth for three wetland plant species grown at four levels of nutrient availability under outdoor conditions for $\mathbf{5 6}$ days

(Means of five replicates + SE). [LSD $(0.05)=15.304$.]

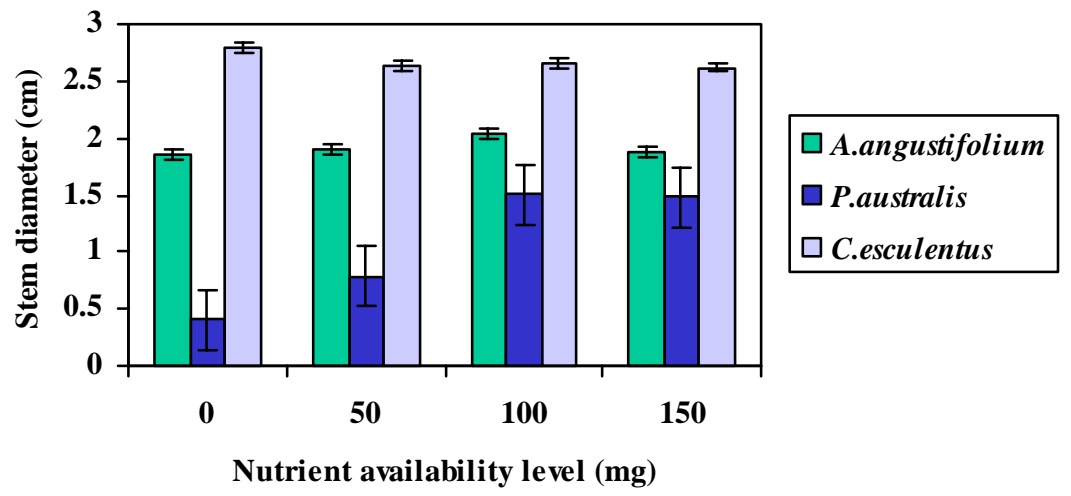

Figure 2. Stem diameter growth for three wetland plant species grown at four levels of nutrient availability under outdoor conditions for $\mathbf{5 6}$ days

(Means of five replicates \pm SE). [LSD $(0.05)=0.257$.]

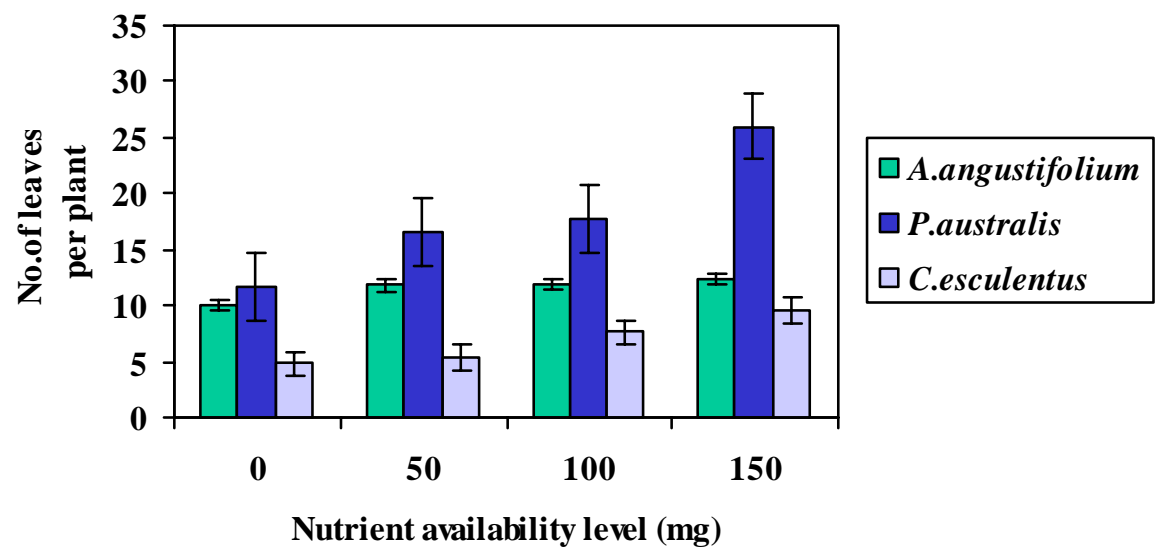

Figure 3. Number of leaves per plant for three wetland plant species grown at four levels nutrient availability under outdoor conditions for $\mathbf{5 6}$ days

(Means of five replicates $\pm S E$ ).

$[\operatorname{LSD}(0.05)=2.1191$. $]$ 
Agric. Biol. J. N. Am., 2010, 1(3): 250-264

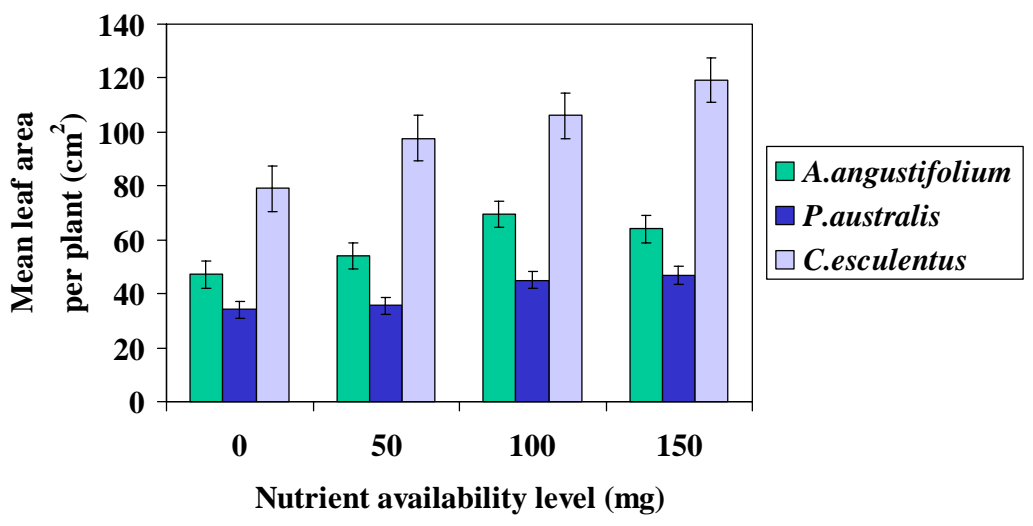

Figure 4. Leaf area for three wetland plant species grown at four levels of nutrient availability under outdoor conditions for 56 days (Means of five replicates \pm SE). [LSD $(0.05)=6.5892$.]

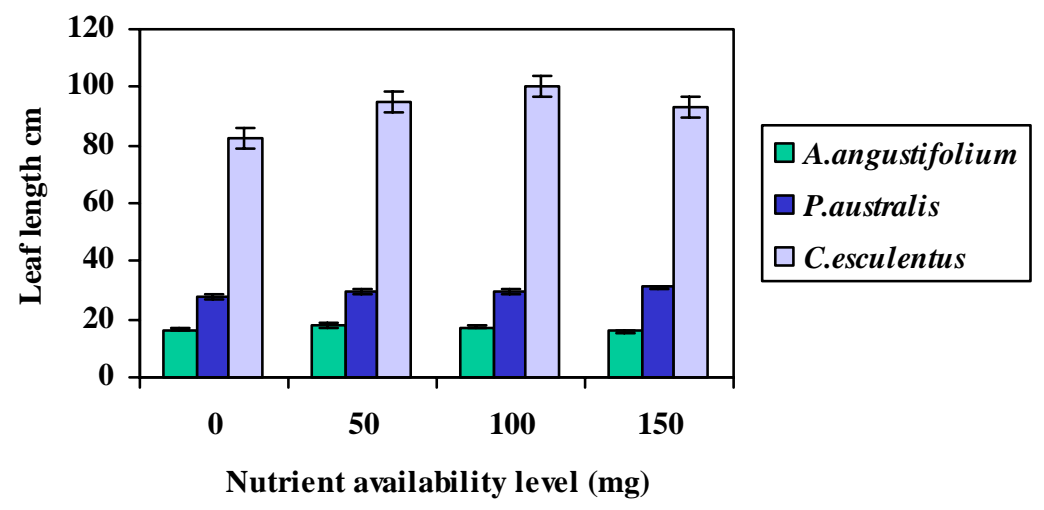

Figure 5. Leaf length for three wetland plant species grown at four levels of nutrient availability under outdoor conditions for 56 days

(Means of five replicates \pm SE). [LSD $(0.05)=3.561$.]

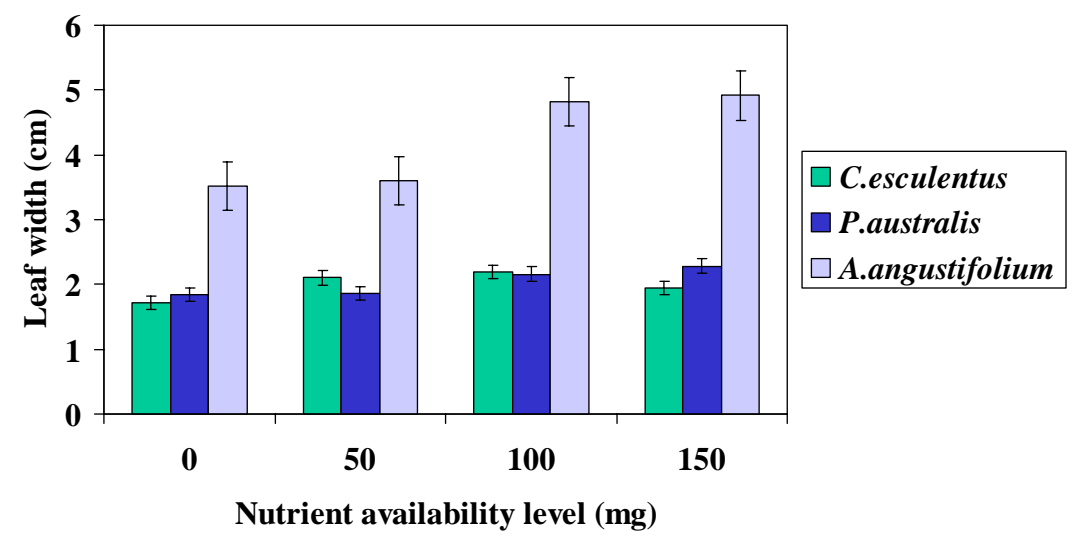

Figure 6. Leaf width for three wetland plant species grown at four levels of nutrient availability under outdoor conditions for 56 days

(Means of five replicates \pm SE). , [LSD $(0.05)=0.2514$.] 
Number of leaves: Increase in nutrient availability increased the number of leaves per plant for the three plant species (Figure 3). However, $P$. australis had significantly $(P \leq 0.05)$ more leaves per plant (a mean of 18.0) compared to $A$. angustifolium (11.1) and $C$. esculentus (6.85). The interactions between the nutrient treatments and species were also significant (Table 1).

Leaf area: The nutrient availability treatments had significant effects $(P \leq 0.05)$ on leaf area increments in all the three species (Figure 4). C. esculentus had the highest leaf area $\left(100.504 \mathrm{~cm}^{2}\right)$ compared to $A$. angustifolium $\left(58.660 \mathrm{~cm}^{2}\right)$ and $P$. australis $\left(40.416 \mathrm{~cm}^{2}\right)$. Analysis of leaf area revealed significant interactions between nutrient treatments and species (Table 1).

Leaf length: Cyperas esculentus had significantly $(P \leq 0.05)$ highest leaf length than $A$. angustifolium and $P$. australis in all nutrient availability treatments (Figure 5). Leaf length per plant slightly increased with increase in nutrient availability especially for $P$.australis while for $C$. esculentus and $A$. angustifolium increased upto $300 \mathrm{mg}$ treatment, and then decreased (Figure 5). There were significant interactions between nutrient treatments and species for this parameter (Table 1).

Leaf width: There were significant differences $(P \leq$ 0.05 ) in leaf width growth among treatments and species (Figure 6).Leaf width slightly increased in $C$. esculentus upto $100 \mathrm{mg}$ nutrient treatment level then decreased. Leaf width growth was most pronounced in $A$. angustifolium, with a mean of $3.965 \mathrm{~cm}$, and $P$. australis with mean of 2.035 and $C$. esculentus with mean of 1.965 , respectively. Interaction effect of nutrient treatments and species was also statistically significant (Table 1).

Shoot fresh weights: Shoot fresh weights increased significantly $(P \leq 0.05)$ with nutrients availability between the treatments and among the species (Figure 7).The most pronounced effect of nutrient availability occurred in Cyperas esculentus while the effect on the other two species was less remarkable. Furthermore, there was a highly significant interaction between nutrient levels and species (Table 1).

weights: Shoot dry weights increased significantly $(P$ $\leq 0.05)$ with nutrient availability in all the species (Figure 8).Cyperas esculentus recorded the highest shoot dry weight with a mean of $24.68 \mathrm{~g}$ compared to $P$. australis with a mean of $18.806 \mathrm{~g}$ and $A$. angustifolium with a mean of $11.875 \mathrm{~g}$, respectively.
There were significant interactions between nutrients and species (Table 1).

Weights: Root fresh weights increased with increasing nutrient availability among the species (Figure 9). Plants under nutrient treatments had significantly $(P \leq 0.05)$ higher root fresh weight than those without nutrient fertilisation (control treatment). Cyperas esculentus had the highest root fresh weight with a mean of $117.015 \mathrm{~g}$ compared to $A$. angustifolium with a mean of $71.885 \mathrm{~g}$, and $P$. australis with a mean of $30.765 \mathrm{~g}$, respectively. There were significant interactions between the nutrient treatments and species for this parameter (Table 1).

Root dry weights: Root dry weights increased with increasing nutrient availability among the species (Figure 10). Cyperas esculentus had the highest root dry weight with a mean of $28.340 \mathrm{~g}$ compared to $P$. australis with a mean of $10.544 \mathrm{~g}$, and $A$. angustifolium with a mean of $10.455 \mathrm{~g}$, respectively. There were significant differences in root dry weights $(P \leq 0.05)$ between the treatments and among the species. There were also significant interactions between the nutrient treatments and species for this parameter (Table 1).

Root-shoot ratio: Root-shoot ratio was significantly $(P \leq 0.05)$ affected by nutrient availability. Root-shoot ratios reduced with increasing nutrient concentration in $C$. esculentus and $A$. angustifolium, while rootshoot ratio increased up to $100 \mathrm{mg}$ then slightly reduced at $150 \mathrm{mg}$ treatment in $P$. australis (Figure 11). Root-shoot ratio was significantly higher for $C$. esculentus with a mean value of 1.32950, than for $A$. angustifolium with a mean value of 1.01127 , and $P$. australis with a mean value of 0.67260 , respectively. There was a significant interaction between the nutrient treatment and the species (Table 1).

\section{Foliar nutrients}

Leaf nitrogen Content: Nitrogen content increased in all nutrient treatments (Figure 12). Phragmites australis had the highest leaf nitrogen content $(2.13 \%$ $\mathrm{N})$, compared to $A$. angustifolium $(1.56 \% \mathrm{~N})$ and $C$. esculentus $(1.3 \% \quad \mathrm{~N})$. There were significant differences $(P \leq 0.05)$ in nitrogen content uptake between the treatments and among the species (Table 2). There was also a significant nutrient treatment and species interactions.

Leaf phosphorus content: There were significant differences $(P \leq 0.05)$ in leaf phosphorus content between treatments and among species (Figure 13). 
Phragmites australis had significantly higher phosphorus content than $A$. angustifolium and $C$. esculentus. Decrease in phosphorus content with increasing nutrient availability occurred in $A$. angustifolium indicating a reduced phosphorus uptake. However, the other two species exhibited higher phosphorus uptake with increasing nutrient availability. There was a significant nutrient treatment $x$ species interactions (Table 2).

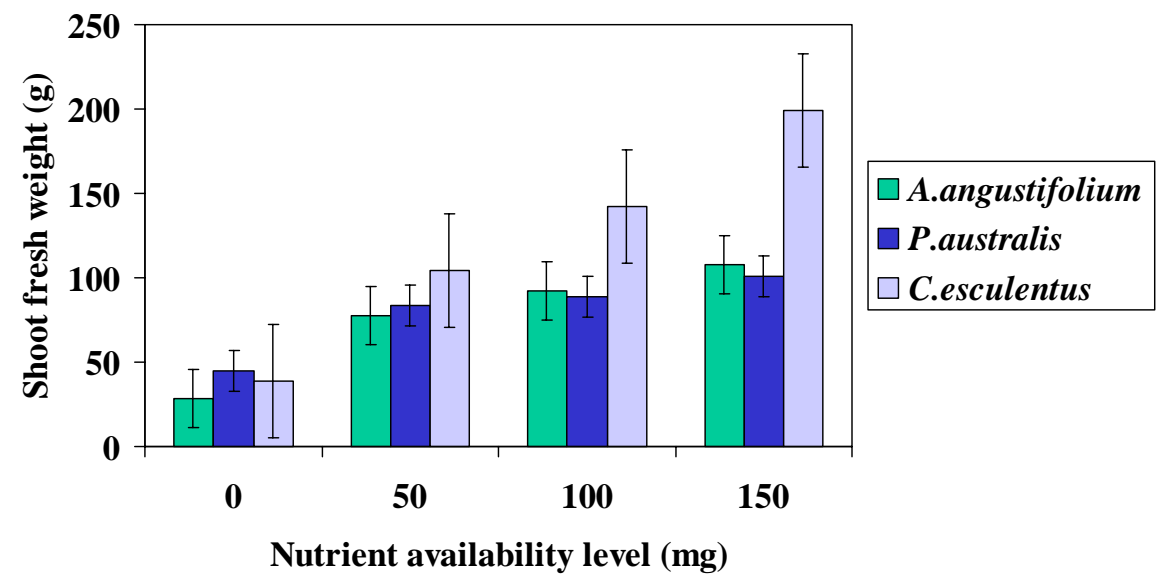

Figure 7. Shoot fresh weight for three wetland plant species grown at four levels of nutrient availability under outdoor conditions for 56 days (Means of five replicates \pm SE). [LSD $(0.05)=$ 15.638.]

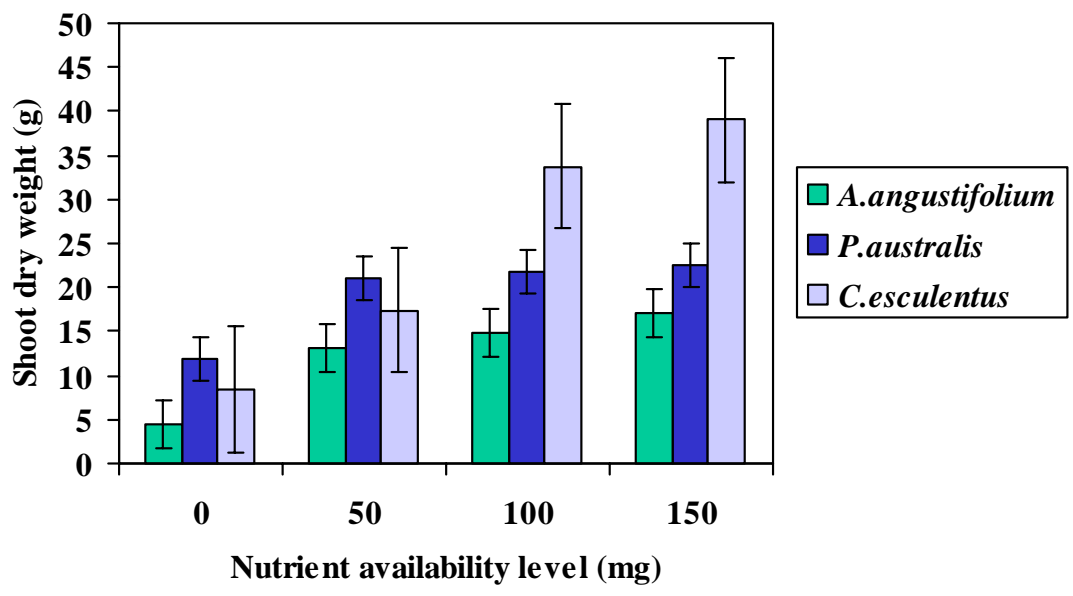

Figure 8. Shoot dry weight for three wetland plant species grown at four levels of nutrient availability under outdoor conditions for 56 days

(Means of five replicates \pm SE). [LSD $(0.05)=3.8542$.] 
Agric. Biol. J. N. Am., 2010, 1(3): 250-264

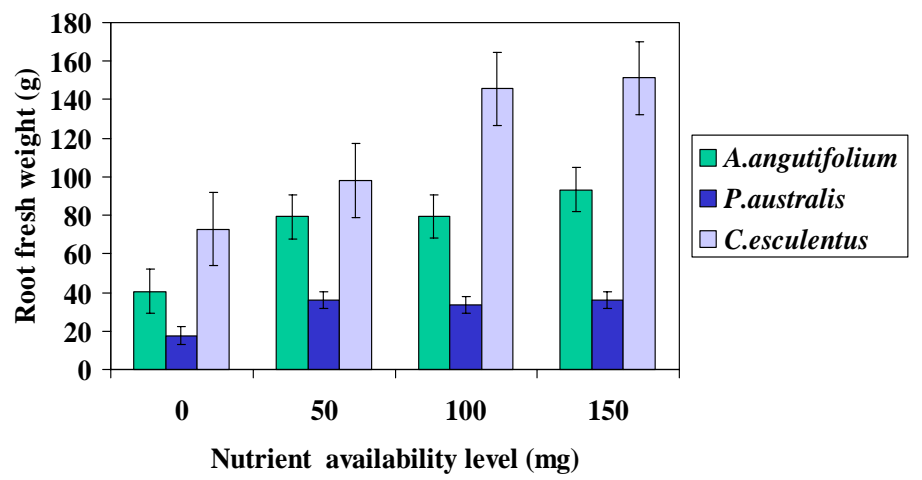

Figure 9. Root fresh weights for three wetland plant species grown at four levels of nutrient availability under outdoor conditions for 56 days (Means of five replicates $\pm \mathrm{SE}$ ). [LSD $(0.05)=16.159$.]

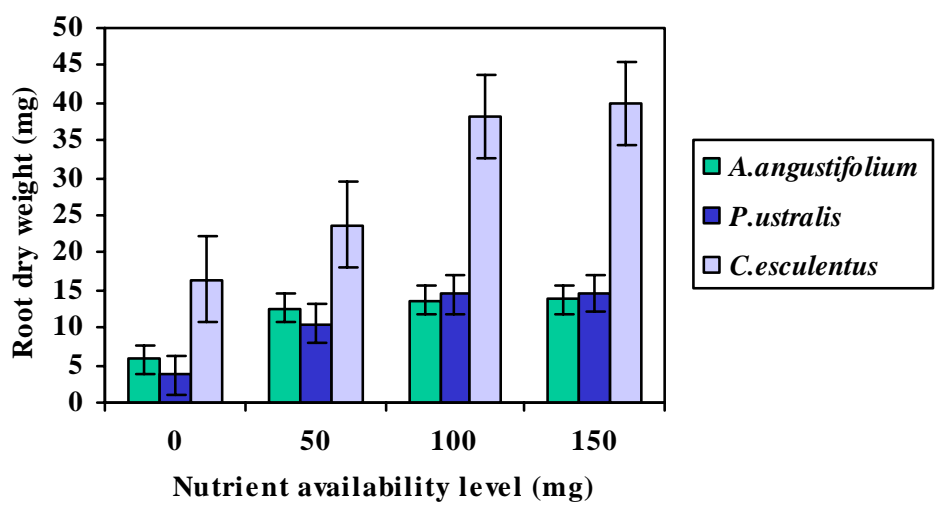

Figure 10. Root dry weight for three wetland plant species grown at four levels of nutrient availability under outdoor conditions for 56 days

(Means of five replicates $+\mathrm{SE})$. [LSD $(0.05)=4.8065$.]

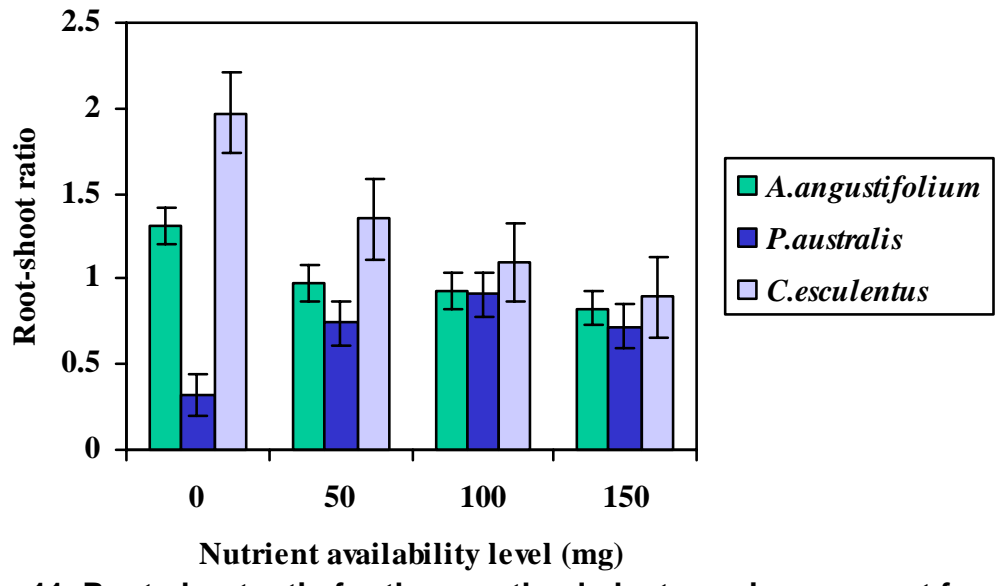

Figure 11. Root-shoot ratio for three wetland plant species grown at four levels of nutrient availability under outdoor conditions for 56 days

(Means of five replicates \pm SE). [LSD $(0.05)=0.2146$.] 
Agric. Biol. J. N. Am., 2010, 1(3): 250-264

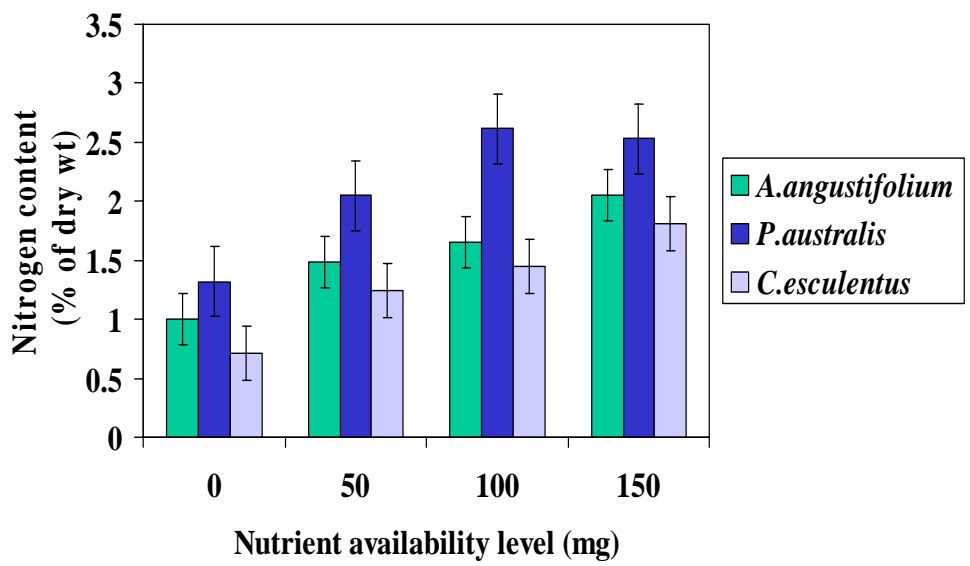

Figure 12. Leaf nitrogen content of three wetland plant species grown at four levels of nutrient availability under outdoor conditions for $\mathbf{5 6}$ days (Means of five replicates \pm SE). [LSD $(0.05)=0.1445$.]

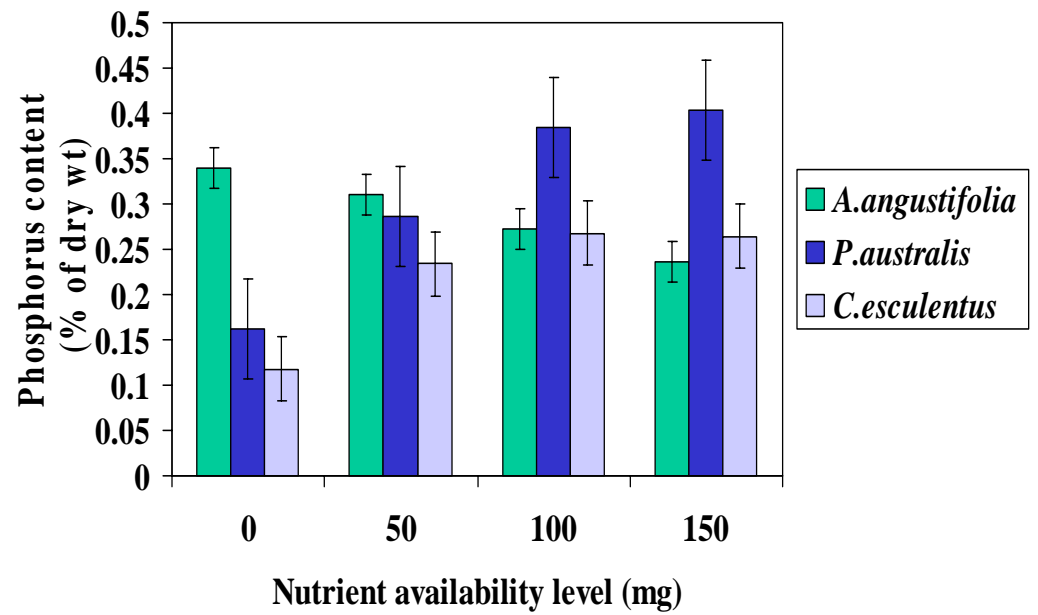

Fig. 13. Leaf phosphorus content for three wetland plant species grown at four levels of nutrient availability under outdoor conditions for 56 days (Means of five replicates \pm SE). $[$ LSD $(0.05)=0.0209$.] 
Agric. Biol. J. N. Am., 2010, 1(3): 250-264

Table 1. Analysis of variance of growth parameters of Cyperas esculentus, Aframomum angustifolium and Phragmites australis grown under various levels of nutrient availability for $\mathbf{5 6}$ days. P values are shown in bold face type.

\begin{tabular}{|c|c|c|c|c|c|}
\hline PARAMETER & SOURCE & DF & MS & & $\mathrm{P}>\mathrm{F}$ \\
\hline & \multicolumn{5}{|c|}{$\mathrm{F}$} \\
\hline \multirow[t]{4}{*}{ Shoot height $(\mathrm{cm})$} & Species (S) & 2 & 29613.2 & 68.47 & $<.0001$ \\
\hline & Treatment $(\mathrm{T})$ & 3 & 573.835 & 573.835 & 0.2778 \\
\hline & $\mathrm{T} \times \mathrm{S}$ & 6 & 443.252 & 1.02 & 0.422 \\
\hline & Error & 44 & 432.487 & & \\
\hline \multirow[t]{4}{*}{ Stem diameter $(\mathrm{cm})$} & Species (S) & 2 & 13.0015 & 106.64 & $<.0001$ \\
\hline & Treatment $(\mathrm{T})$ & 3 & 0.42061 & 3.45 & 0.0244 \\
\hline & $\mathrm{T} \times \mathrm{S}$ & 6 & 0.56246 & 4.61 & 0.001 \\
\hline & Error & 44 & 0.12192 & & \\
\hline \multirow[t]{4}{*}{ Leaf area $\left(\mathrm{cm}^{2}\right)$} & Species (S) & 2 & 1899.445 & 236.76 & $<.0001$ \\
\hline & Treatment $(\mathrm{T})$ & 3 & 1700.36 & 21.21 & $<.0001$ \\
\hline & $\mathrm{T} \times \mathrm{S}$ & 6 & 211.73 & 2.64 & 0.0283 \\
\hline & Error & 44 & 80.1709 & & \\
\hline \multirow[t]{4}{*}{ Leaf number } & Species (S) & 2 & 633.317 & 76.38 & $<.0001$ \\
\hline & Treatment $(\mathrm{T})$ & 3 & 121.306 & 14.63 & $<.0001$ \\
\hline & $\mathrm{T} \times \mathrm{S}$ & 6 & 42.0056 & 5.07 & 0.0005 \\
\hline & Error & 44 & 8.29167 & & \\
\hline \multirow[t]{4}{*}{ Leaf length $(\mathrm{cm})$} & Species (S) & 2 & 33108.9 & 1414 & $<.0001$ \\
\hline & Treatment $(\mathrm{T})$ & 3 & 119.852 & 5.12 & 0.004 \\
\hline & $\mathrm{T} \times \mathrm{S}$ & 6 & 89.5334 & 3.82 & 0.0037 \\
\hline & Error & 44 & 23.4151 & & \\
\hline \multirow[t]{4}{*}{ Leaf width $(\mathrm{cm})$} & Species (S) & 2 & 25.7660 & 220.84 & $<.0001$ \\
\hline & Treatment $(\mathrm{T})$ & 3 & 1.3095 & 11.22 & $<.0001$ \\
\hline & $\mathrm{T} \times \mathrm{S}$ & 6 & 0.50333 & 4.31 & 0.0017 \\
\hline & Error & 44 & 0.11667 & & \\
\hline \multirow[t]{4}{*}{ Root fresh weight $(\mathrm{g})$} & Species (S) & 2 & 37222.1 & 77.2 & $<.0001$ \\
\hline & Treatment $(\mathrm{T})$ & 3 & 7108.72 & 14.74 & $<.0001$ \\
\hline & $\mathrm{T} \times \mathrm{S}$ & 6 & 1492.1 & 3.09 & 0.0129 \\
\hline & Error & 44 & 482.128 & & \\
\hline \multirow[t]{4}{*}{ Root dry weight (g) } & Species (S) & 2 & 2121.93 & 49.74 & $<.0001$ \\
\hline & Treatment $(T)$ & 3 & 490.978944 & 11.51 & $<.0001$ \\
\hline & $\mathrm{T} \times \mathrm{S}$ & 6 & 97.5669 & 2.29 & 0.0523 \\
\hline & Error & 44 & 42.659 & & \\
\hline \multirow[t]{4}{*}{ Shoot fresh weight $(\mathrm{g})$} & Species (S) & 2 & 12512.56 & 27.71 & $<.0001$ \\
\hline & Treatment $(\mathrm{T})$ & 3 & 25835.5 & 57.21 & $<.0001$ \\
\hline & $\mathrm{T} \times \mathrm{S}$ & 6 & 2772.33 & 6.14 & $<.0001$ \\
\hline & Error & 44 & 451.564 & & \\
\hline \multirow[t]{4}{*}{ Shoot dry weight (g) } & Species (S) & 2 & 821.699 & 29.96 & $<.0001$ \\
\hline & Treatment $(\mathrm{T})$ & 3 & 893.181 & 32.56 & $<.0001$ \\
\hline & $\mathrm{T} \times \mathrm{S}$ & 6 & 183.298 & 6.68 & $<.0001$ \\
\hline & Error & 44 & 27.4303 & & \\
\hline \multirow[t]{4}{*}{ Root: shoot ratio } & Species (S) & 2 & 2.15828 & 25.38 & $<.0001$ \\
\hline & Treatment $(\mathrm{T})$ & 3 & 0.37762 & 4.44 & 0.0082 \\
\hline & $\mathrm{T} \times \mathrm{S}$ & 6 & 0.62639 & 7.37 & $<.0001$ \\
\hline & Error & 44 & 0.08504 & & \\
\hline
\end{tabular}


Table 2. Analysis of variance in leaf nitrogen content and leaf phosphorus content of Cyperas esculentus, Aframomum angustifolium and Phragmites australis grown under various levels of nutrient availability for $\mathbf{5 6}$ days. $P$ values are shown in bold face type.

\begin{tabular}{|c|c|c|c|c|c|}
\hline PARAMETER & SOURCE & DF & MS & $\mathrm{F}$ & $P>F$ \\
\hline \multirow[t]{4}{*}{ Leaf nitrogen content ( $\%$ of dry wt) } & Species (S) & 2 & 3.58997 & 93.16 & $<.0001$ \\
\hline & Treatment $(\mathrm{T})$ & 3 & 3.53562 & 91.75 & $<.0001$ \\
\hline & $\mathrm{T} \times \mathrm{S}$ & 6 & 0.10904 & 2.83 & 0.0204 \\
\hline & Error & 44 & 0.03853 & & \\
\hline \multirow[t]{4}{*}{ Leaf phosphorus content ( $\%$ of dry wt) } & Species (S) & 2 & 0.04272 & 53.08 & $<.0001$ \\
\hline & Treatment $(\mathrm{T})$ & 3 & 0.03221 & 40.01 & $<.0001$ \\
\hline & $\mathrm{T} \times \mathrm{S}$ & 6 & 0.03203 & 39.8 & $<.0001$ \\
\hline & Error & 44 & 0.0008 & & \\
\hline
\end{tabular}

\section{DISCUSSION}

Plant height was significantly increased by nutrient availability (Figure 1), this agrees well with the findings by Naidoo (2009) working with dwarf Avicennia marina mangroves. Increase in plant height of the three plant species with increase in nutrient availability may be attributed to increased rates of photosynthesis as a result of increased leaf chlorophyll synthesis, and increased nutrient use efficiencies of these species. Previous studies by Naidoo (2009) and Lovelock et al. (2009) indicated the shift of resource allocation to shoots which enhance growth and productivity with nutrient enrichment of plants. Stem diameter of $A$. australis steadily increased with increase in nutrients availability from 0 to $100 \mathrm{mg}$ treatment and then stabilised between $100 \mathrm{mgand} 150 \mathrm{mg}$, this increase may suggest an increase cell size and cell number as a result of increased cell division and cell expansion, leading to increased stem diameter growth. Stem diameter of both $C$. esculentus and $A$. angustifolium decreased slightly with increase in nutrient availability (Figure 2), the slight decrease in stem diameter may be attributed to the increase in the number of tillers in the pots leading to inhibition in stem growth as competition for resources set in. In a plant monoculture that does not self thin, many investigators have shown growth inhibition may occur when individuals compete for resources (Wang et al., 2005).

Number of leaves per plant for the three species significantly increased with nutrient availability (Figure 3), however the increase was more pronounced in $P$. australis. Increase in leaf number with increasing nutrient availability may lead to increased photosynthetic rates, and subsequently to increase absolute allocations to other plant organs.
This increase in leaf number especially in $P$. australis may be a physiological characteristic of increasing the invasiveness of this species.

There was an increase in leaf area with increase in nutrient availability (Figure 4). The results agree with the studies by Oberbauer et al. (2006), who found that the addition of fertilizer caused large increases in leaf area production for all species tested. The increase in leaf area with increased nutrient availability may be a consequence of increased meristematic activities, due to increased supply of nitrogen to drive shoots growth and photosynthesis, and also of increased cell expansion. The observed differences among plant species in leaf area growth may result from differences in total carbon assimilation or nutrient uptake.

Leaf area affects dry matter production and plant growth through its role in light interception (Jones, 1992). Vos and Van der Putten (1998) reported a decrease in the area of individual leaves with decreasing $\mathrm{N}$ fertility. The relative impact of $\mathrm{N}$ on cell division and cell expansion depends on the developmental stage of the leaf (del Amor, 2006). Physiological characteristics such as leaf area may also impact the invasiveness of plants (Smith et al., 2008). Increased nutrient availability therefore may likely stimulate growth of these species and improve their competitiveness for invasion.

Measurements of leaf width, leaf length and leaf area are indicators of leaf expansion. Both leaf width and leaf length increased with increase in nutrient availability among the species (Figures 5 and 6 ). Increase in leaf width was most pronounced in $A$. angustifolium, while leaf width in $C$. esculentus increased upto $100 \mathrm{mg}$ then decreased. These results are partly in agreement with previous studies by del 
Amor (2006), where it was reported that organic N treatment progressively reduced both leaf length and width. Decrease in leaf width and length with increase in nutrient availability in this study may be attributed to reduction in cell expansion as it has been proposed earlier by del Amor (2006), that relative impact of $\mathrm{N}$ on cell division and cell expansion depends on the developmental stage of the leaf. It is also possible that reduction in leaf width and leaf length may have occurred due to competition for resources by the plants because the number of tillers per pot increased with increasing nutrient availability. Growth of plants at high density may lead to growth inhibition of plants as a result of competition (Wang et al., 2005). Many investigators have shown that a biomass distribution consisting of a few large plants and many small plants may develop when individuals compete for resources (Weiner, 1986; Wang et al., 2005). In previous study by Wang et al. (2006), dry mass production of $A$. prostrate decreased significantly in the higher density treatments. High density treatments indicated declines in height, leaf area, and biomass of stems, leaves and roots in A. prostate (Wang et al., 2005). Previous studies have indicated that increased atmospheric nitrogen deposition alters the species composition and functioning of most natural and semi-natural plant communities (Bobbink et al., 1998). Many changes are typical of nutrient enrichment, including increased biomass production, dominance of faster growing plant species, accelerated $\mathrm{N}$ cycling and reduced $\mathrm{N}$ retention (Güsewell, 2005).

Many observations made over a range of nitrogen availability in the environment suggest the existence of a compulsory balance between nitrogen and carbon nutrition. This explains why plants optimise their carbon gains in relation to the nitrogen available for photosynthesis (Field, 1983), and why a reduction in leaf photosynthesis leads to a reduction in growth. Low nutrient availability usually results in an increase of plant root capacity for nutrient uptake, an increase of dry matter allocation to roots and a decrease in tissue nutrient content (del Amor, 2006).

Both fresh and dry weights of the three species of shoots and roots increased with increasing nutrient availability (Figures 7, 8, 9 and 10). The most pronounced effect of nutrient availability on both fresh and dry shoot and root weights occurred in $C$. esculentus in comparison to $P$. australis and $A$. angustifolium, indicating a greater ability of $C$. esculentus to compete for below ground resources.
This fact indicates it will have even greater impacts on wetland ecosystems and an increased need for control in a future nutrient enriched environment. Our results agree well with the findings by Sharoar et al. (2006), where NPK fertilizer was effective in increasing final plant weight.

Root-shoot ratio decreased with increasing nutrient availability in $A$. angustifolium and $C$. esculentus (Figure 11). However, root-shoot ratio increased in $P$. australis up to $100 \mathrm{mg}$, and then slightly reduced at $150 \mathrm{mg}$. Reduction in root-shoot ratios of the plants with increasing nutrient availability signifies greater leaf production rates and leaf area expansion, leading to increased biomass accumulation. As nutrient availability increases, plants invest less in roots and more in aboveground parts, thereby further enhancing growth rates (Lovelock et al., 2009). An increase in root to shoot ratio as noted in $P$. australis, may be attributed mainly to a reduction in shoot growth, as has been observed when water is limiting (Osório et al., 1998; Masinde et al., 2005), but none of the plants were wilted at any time during the experimental period, there was no visible indication that water stress was a problem, and because water and nutrients were provided regularly and were not limiting in this experiment, water stress had no effects on root-shoot ratio. Therefore increase in root-shoot ratio under increasing nutrient availability may be attributed to decreased foliage area and intercepted solar radiation. Based on these data, we can conclude that genetic control over the root: shoot ratio is very strong in $C$. esculentus and $A$. angustifolium.

According to Sharoar, (2006), in an experiment with rapeseed and turnip, it was observed that high $\mathrm{N}$ treated plants had lower leaf area and total dry weight up to 25 days after sowing but after that period leaf area and dry weight were increased significantly by increasing $\mathrm{N}$ levels. Reduced leaf area and leaf $\mathrm{N}$ content should result in lower rates of photosynthesis at a time when reproduction is becoming a major sink for carbon and nutrients (Benner and Bazzaz, 1988). Reduction in leaf area is also likely to reduce stomatal conductance and transpiration rate, and this may decrease the rate of mass flow of nutrients into the plant (Wang et al., 2006). None of the plants wilted at any point, indicating that water stress was not a problem. Nutrient availability can affect photosynthetic or growth rates or both and thereby influence carbon allocation decisions as well (Benner and Bazzaz, 1988). 
The results show that the $\mathrm{N}$ and $\mathrm{P}$ elements are distributed independently of each other, as found in previous studies (Benner and Bazzaz, 1988; del Amor, 2006).Such differences may result from variation in the requirements of different plant tissues for the elements, for example, the requirement for $\mathrm{N}$ in leaves is likely to be very high, especially early in plant growth, because photosynthetic rate is closely related to leaf $\mathrm{N}$ content (Amaya-Carpio et al., 2005; del Amor, 2006).As the nutrient availability increased, the accumulation of elements $\mathrm{N}$ and $\mathrm{P}$ tended to increase, probably reflecting the effects of a larger root system, greater leaf area for transpiration, and higher photosynthetic rates of the plants.

Mean leaf $\mathrm{N}$ and $\mathrm{P}$ of the species tested increased slightly with increasing nutrient availability (Figures 12 and 13). Phragmites australis had significantly higher leaf $\mathrm{N}$ and $\mathrm{P}$ than the two other species. In the current study, the $C$. esculentus had the lowest foliar $\mathrm{N}$, and $P$. australis had the highest $\mathrm{N}$ and $\mathrm{P}$, suggesting that the invasion of $P$. australis into communities dominated by $C$. esculentus and $A$. angustifolium could dramatically alter the nutrient dynamics of the wetland. The results compares well with the findings reported by Oberbauer et al. (2006). The differences in leaf accumulation of $\mathrm{N}$ and $\mathrm{P}$ among the treatments and species may be reflected by the differences in up take dynamics of $\mathrm{N}$ and $\mathrm{P}$ resulting from the greater insolubility of phosphate compounds and their adsorption on to soil particles ((Benner and Bazzaz, 1988). Maximum photosynthetic capacity is strongly regulated by leaf nitrogen concentration (Yao et al., 2008). Phosphorus is also an important element that is also required for photosynthetic energy production and carbohydrate transport (De Groot et al., 2003).

Phosphorus limitation may affect photosynthesis through changes in the activity of Calvin enzymes, RuBP regeneration or Rubisco activity (De Groot et al., 2003). Nitrogen content in the roots may be diluted by increased dry mater (Martinez et al., 2005), which may impair root growth and as a result the insufficient $\mathrm{N}$ supply depresses the leaf area and thus plants may not maintain leaf expansion and stem elongation at the expense of roots. Factors such as root morphology, nitrate transporters and source sink relationships for carbohydrate energy may impact $\mathrm{N}$ and $\mathrm{P}$ uptake and assimilation by plants. Nutrients particularly $\mathrm{N}$, stimulate growth of shoots relative to roots (Lovelock et al., 2009), thereby enhancing productivity during favourable periods but increasing vulnerability to stress.
Foliar nitrogen and phosphorus were significantly higher in $P$. australis than in the other two species (Figures 12 and 13), suggesting that this species accrues nutrients more efficiently compared to $C$. esculentus and $A$. angustifolium. This finding is in agreement with the results reported by Farnsworth and Meyerson (2003). Leaf $N$ and $P$ values were within the range for improved pasture wetlands, between $0.16-0.24 \%, \mathrm{P}$ and mean $\mathrm{N}$ concentration of $1.9 \%$ (Gathumbi et al., 2005). Mean N concentration in plant tissues was greater in plants grown at higher nutrient availability levels than in control treatments. Nitrogen is an essential component of all enzymes and phosphorus is vital for protein synthesis forming an essential component of RNA (Lovelock et al., 2007). The concentration of $N$ and $P$ in tissues also influences the rates of ecological processes, for example, grazing, parasitism and decomposition have been observed to be influenced by the stoichiometery of $\mathrm{N}$ and $\mathrm{P}$ within tissues (Lovelock et al., 2007). Soil $N$ and $P$ concentrations decrease with soil depth in wetlands, and ranges from 0.2 to $1.7 \% \mathrm{~N}$ and 0.004 to $0.06 \%$ for P (Gathumbi et al., 2005).

Agroforestry is widely called upon to reclaim degraded land ecosystems. Types of land degradation include soil erosion, soil fertility decline, salinization, water-resouce degradation, forest clearance and degradation and loss of biodiversity (Young, 1989). Phragmites australis due to its ability to sequester high concentrations of nitrogen and phosphorus in foliar tissues qualifies this species as a better agroforestry plant species for reclaiming wetland areas. Cyperas esculentus and Aframomum angustifolium also prove as a good agroforestry species because of their ability to accumulate greater biomass very fast hence they can be used as multipurpose tree species in agroforestry systems especially in wetland areas. The three species could be introduced in wetland areas to reinforce the conservation and management of the degraded wetlands.

\section{CONCLUSIONS}

In summary, nutrient availability treatments significantly influenced the morphological and biochemical parameters investigated. Shoot height, stem diameter, leaf area, leaf number, shoot and root weights were all impacted by nutrient availability treatments. Cyperas esculentus and $A$. angustifolium had higher rate of biomass accumulation as evidenced by increase in shoot and root weights compared to $P$. australis. Cyperas esculentus showed a higher photosynthetic activity compared to 
A. angustifolium and $P$. australis, at increasing nutrient availability. Increase in photosynthetic capacity of these plants also contributed to increased biomass accumulation as evidenced by increase in shoot and root dry weights.

Because water and nutrients were not limiting under the experimental setting, competition for resources such as light due to crowding could be the main reason that contributed to reduction in growth and nutrient uptake of the plants. Cyperas esculentus appeared to be more adapted to grow in increased nutrient availability than $A$. angustifolium and $P$. australis. The results suggest that wetland nutrient enrichment may potentially lead to alteration of the species composition and functions of the wetland ecosystems.

\section{REFERENCES}

Aerts R. and Chapin F.S (2000). The mineral nutrition of wild plants revisited: a re-evaluation of processes and patterns. Adv Ecol Res30: 1-67.

Amaya-Carpio L., Davies F.T. and Arnold M.A. (2005). Arbuscular Mycorrhizal Fungi,organic and inorganic controlled-release fertilizers: Effect on growth and leachate of container-grown bush Morning Glory (Ipomoea carnea ssp. Fistulosa) under high production temperatures. J Am Soc Hort Sci130 (1): 131-139.

Benner B.L. and Bazzaz F.A. (1988). Carbon and mineral element accumulation and allocation in two annual plant species in response to timing of nutrient addition. J Ecol 76: 19-40.

Bobbink R., Hornung M. and Roelofs J.G.M. (1998).The effects of air-borne nitrogen pollutants on species diversity in natural and semi-natural European vegetation- a review. J Ecol 86: 717-738.

De Groot C.C., Van den Boogaard R., Marcelis L.F.M., Harbinson J. and Lambers H. (2003). Contrasting effects of $\mathrm{N}$ and $\mathrm{P}$ deprivation on the regulation of photosynthesis in tomato plants in relation to feedback limitation. J Exper Bot 54 (389): 1957-1967.

del Amor F.M. (2006). Growth, photosynthesis and chlorophyll fluorescence of sweet pepper plants as affected by the cultivation method. Annals of Applied Biol 148: 133-139.

Farnsworth E.J. and Meyerson L.A. (2003).Comparative ecophysiology of four wetland plant species along a continuum of invasiveness. Wetlands 23 (4): 750-762.

Field C. (1983). Allocating leaf nitrogen for the maximization of carbon gain: leaf age as a control on the allocation program. Oecologia 56: 341-347.

Galatowitsch S.M., Whited D.C., Lehtinen R., Husveth J. and Schik K. (2000). The vegetation of wet meadows in relation to their land-use. Environmental Monitoring and Assessment 60: 121-144.

Gathumbi S.M., Bohlen P.J. and Graetz D.A. (2005) .Nutrient enrichment of wetland vegetation and sediments in Subtropical pastures. Soil Sci Soc America J. 69:539-548.

Güsewell S. (2005). High nitrogen: phosphorus ratios reduce nutrient retention and second -year growth of Wetland sedges. New Phytologist 166: 537-550.

Jackson M.B. and Colmer T.D. (2005). Response and adaptation by plants to flooding stress. Annals of Botany 96: 501-505.

Janiesch P. (1991).Ecophysiological adaptations of higher plants in natural communities to waterlogging. In: J. Rozema and J.A.C. Verkleij (eds.), Ecological responses to environmental stresses.Kluwer Academic Publishers, Netherlands, pp. 50-60.

Jones H.G. (1992). Plants and microclimate: A quantitative approach to environmental plant physiology. $2^{\text {nd }}$ edition, Cambridge Univ. Press,New York.

Jones M.B. and Muthuri F.M. 1985. The canopy structure and microclimate of Papyrus (Cyperus papyrus) swamps. J Ecol. 73 (2): 481-491.

Lovelock C.E., Feller I.C., Ball M.C., Ellis J. and Sorrell B. (2007). Testing the Growth Rate vs. Geochemical Hypothesis for latitudinal variation in plant nutrients. Ecology Letters, 10: 1154-1163.

Lovelock C.E.,Ball M.C., Martin K.C. and Feller I.C.(2009). Nutrient enrichment increases mortality of mangroves. PLOSONE 4 e5600.doi:10.1371/journal.pone.0005600

Martinez V., Del Amor F.M. and Marcelis L.F.M. (2005). Growth and physiological response of tomato plants to different periods of nitrogen starvation and recovery. $\mathrm{J}$ Hort Sci Biotechnol 80: 147-153.

Masinde P.W., Stutzel H., Agong S.G. and Fricke A. (2005). Plant growth, water relations, and transpiration of Spiderplant [Gynandopsis gynadra (L.) Briq.] under water limited conditions. J Am Soc Hort Sci 130(3): 469-477

Naidoo G. (2009) .Differential effects of nitrogen and phosphorus enrichment on growth of dwarf Avicennia marina mangroves. Aquatic Botany 90 (2): 184-190.

Neubauer S.C., Miller W.D., and Anderson I.C. (2000). Carbon cycling in a tidal freshwater marsh ecosystem: a carbon gas flux study. Marine Ecology Progress Series. 199: 13-30.

Oberbauer S.F., Hastings S.J., Beyers J.L. and Oechel W.C. (2006). Comparative effects of downslope water and nutrient movement on plant nutrition, photosynthesis, and growth in Alaskan tundra. Ecography 12 (3): 324-334. 
Osório J.,Osório M.L.,Chaves M.M. and Pereira J.S. (1998). Water deficits are more important in delaying growth than in changing patterns of carbon allocation in Eucalyptus globules. Tree physiol 18: 363-373.

Pons T.L. and Westbeek M.H.M. (2004). Analysis of differences in photosynthetic nitrogen-use efficiency between four contrasting species. Physiologia Plantarum 122: 68-78.

Poorter H. and Nagel O. (2000). The role of biomass allocation in the growth response of plants to different levels of light, $\mathrm{CO}_{2}$, nutrients and water: a quantitative review. Aust J Plant Physiol 27: 595-607.

Qualls R.G., and Richardson C.J. (1995). Forms of phosphurus along a nutrient enrichment gradient in the northern everglades. Soil Sci 160:183-198.

Richardson A.D., Duigan S.P. and Berlyn G.P. (2002). An evaluation of non invasive methods to estimate foliar chlorophyll content. New Phytologist 153:185-194.

Rozema J. and Leendertse P.C.(1991). Natural and manmade environmental stresses in coastal wetlands. In: J. Rozema and J.A.C. Verkleij (eds.), Ecological responses to environmental stresses. Kluwer Academic Publishers, Netherlands, pp. 92-101

Sharoar M,G., Deb A.C. and Khaleque M.A., (2006). Effect of different ages on some root characters, Nodules and yield components in Blackgram (Vigna mungo (L.)Hepper).Asian J Plant Sci. 5(4): 717-720.

Smith K.E., Runion G.B., Prior S.A., Price A.J., Rogers H.H. and Torbert H.A. (2008). Chinese Privet
(Ligustrum sinense) in an elevated $\mathrm{CO}_{2}$ environment. Bot $\operatorname{Re} J$ 1(2): 43-48.

Tilman D. (1987). On the meaning of competition and the mechanisms of competitive superiority. Functional Ecology 1: 304-315.

Tilman D., Knops J., Wedin D., Reich P., Ritchie M. and Siemann E. (1997). The influence of functional diversity and composition on ecosystem processes. Science 277: 1300-1302.

Vos J., Van der Putten P.E.L. (1998). Effect of nitrogen supply on leaf growth, leaf nitrogen economy and photosynthetic capacity of potato. Field Crops Res 59: 63-72.

Wang L., Showalter A.M. and Ungar I.A. (2005). Effects of intraspeciffic competition on growth and photosynthesis of Atriplex prostrate. Aquatic Botany 83:187-192.

Weiner J. (1986). How competition for light and nutrients affects size variability in I pomoea tricolor. Ecology 67:1425-1427.

Yao X., Liu Q. and Han C. (2008). Growth and photosynthetic responses of Picea asperata seedlings to enhanced ultraviolet-B and to nitrogen supply. Brazilian J Plant Physiol 20(1): 11-18.

Young A. (1989). Agroforestry for soil conservation. Science and practice of agroforestry, No. 4. Nairobi: ICRAF, Pp 11-13. 